Louisiana State University

LSU Digital Commons

Faculty Publications

Department of Biological Sciences

$1-1-2007$

\title{
Impact of the developmental appropriateness of teacher guidance strategies on kindergarten children's interpersonal relations
}

\author{
Hardee M. Schmidt \\ Louisiana State University \\ Diane C. Burts \\ Louisiana State University \\ R. Sean Durham \\ Louisiana State University \\ Rosalind Charlesworth \\ Weber State University \\ Craig H. Hart \\ Brigham Young University
}

Follow this and additional works at: https://digitalcommons.Isu.edu/biosci_pubs

\section{Recommended Citation}

Schmidt, H., Burts, D., Durham, R., Charlesworth, R., \& Hart, C. (2007). Impact of the developmental appropriateness of teacher guidance strategies on kindergarten children's interpersonal relations. Journal of Research in Childhood Education, 21 (3), 290-301. https://doi.org/10.1080/02568540709594595

This Article is brought to you for free and open access by the Department of Biological Sciences at LSU Digital Commons. It has been accepted for inclusion in Faculty Publications by an authorized administrator of LSU Digital Commons. For more information, please contact ir@lsu.edu. 


\section{Impact of the Developmental Appropriateness of Teacher Guidance Strategies on Kindergarten Children's Interpersonal Relations}

Hardee M. Schmidt, Diane C. Burts , R. Sean Durham, Rosalind Charlesworth \& Craig H. Hart

To cite this article: Hardee M. Schmidt, Diane C. Burts , R. Sean Durham , Rosalind Charlesworth \& Craig H. Hart (2007) Impact of the Developmental Appropriateness of Teacher Guidance Strategies on Kindergarten Children's Interpersonal Relations, Journal of Research in Childhood Education, 21:3, 290-301, DOI: 10.1080/02568540709594595

To link to this article: https://doi.org/10.1080/02568540709594595



Submit your article to this journal

山ll Article views: 454

View related articles 5

Citing articles: 2 View citing articles $₫$ 


\title{
Impact of the Developmental Appropriateness of Teacher Guidance Strategies on Kindergarten Children's Interpersonal Relations
}

\author{
Hardee M. Schmidt * \\ Diane C. Burts \\ R. Sean Durham \\ Louisiana State University \\ Rosalind Charlesworth \\ Weber State University \\ Craig H. Hart \\ Brigham Young University
}

\begin{abstract}
This initial study explored the social behaviors of kindergarten children in two classrooms (one developmentally appropriate, one developmentally inappropriate) where the teacher used either positive or negative guidance strategies. Six pairs of kindergartners - three dyads (boy-boy, girl-girl, boy-girl) from a classroom in which the teacher used positive guidance strategies and three from a classroom where the teacher used negative guidance strategies-were observed while playing in a researcher-designed play center. Observations over a three-month period revealed an increase in positive social behaviors among children from the positive guidance classroom and a decrease in positive social behaviors among children from the negative guidance classroom. Implications are discussed.
\end{abstract}

Student accountability is a critical issue in contemporary American education. Since the implementation of No Child Left Behind (2002), schools, teachers, and, ultimately, children, have faced increased scrutiny and pressure to provide evidence of academic achievement (McDaniel, Isaac, Brooks, $\&$ Hatch, 2005). The idea that the more children learn at younger ages the more success they will have in school has resulted

\footnotetext{
*Authors' Note: This manuscript is based on the master's thesis of Hardee M. Schmidt and is a tribute to her work. Hardee felt passionately about the manner in which young children are treated. In her words, "This study was inspired by a concern that violence prevention should begin in early childhood, rather than later, when children are already involved in the legal system. . . C Curing social ills may lie at the beginning of a child's life, rather than at prison's door." Tragically, Hardee was killed in May of 1999 by an alleged serial killer.
}

in increased direct teaching and standardized testing in programs for young children (Blaustein, 2005). But, academics are not the only things learned in school. All schools, whether they intend to or not, influence children's social and moral development. DeVries and Zan (1994) assert that schools are not value-free or value-neutral and that non-academic inputs, such as discipline techniques, expectations, and classroom control mechanisms, bear strongly upon children's development. It can be argued that the hidden curriculum may influence child outcomes as much as what is deliberately taught. One important consideration is how school experiences shape children's sociomoral development.

The ability of a child to negotiate social relationships has been related to a wide range of outcomes. The importance of children gaining relationship-oriented competencies is highlighted by studies suggesting that 
such long-term problems as delinquency, school drop-out, and psychological disturbances accompany unsuccessful childhood social relationships (Ladd, Buhs, \& Troop, 2002). Conversely, the ability to form positive social relationships has been described as a significant skill enabling a child to do better in school and, therefore, life (Pianta, 1999). Although researchers have documented the influence of parenting upon children's peer relations (see Hart, Newell, \& Olsen, 2003 for a review), today's children are spending increased time away from their parents in school or early care settings. Data provided by the National Association for the Education of Young Children (NAEYC, 2005) indicates that in 2003, 64 percent of mothers with children under 6 years old were in the labor force. From the earliest years, many children are spending a majority of their days under the care and influence of adults other than their parents. NAEYC also reports that 43 states are now funding pre-kindergarten programs. The reality is that the experience of attending school or other early care and education programs is having an impact upon children at earlier ages. The potential implications of this increased exposure warrant an examination of the many opportunities that early care and education programs have to affect children's sociomoral development.

In addition to learning to read and write, learning to relate to others is a worthy educational goal. Those in the field of early childhood education have argued in favor of practices that emphasize social relationships within classrooms. Dewey envisioned that the classroom atmosphere could bring about a fuller realization of democratic ideals (Parke, Ornstein, Rieser, \& Zahn-Waxler, 1994). Piaget (1932/1965) recognized the value of interpersonal relationships as a context for the construction of moral thought and as critical to an understanding of early education. Recently, educators have voiced the opinion that the early childhood classroom is the first place that democratic values are tested (Teaching Tolerance, 1997). The guidelines for developmentally appropri- ate practice (DAP) published by NAEYC acknowledge the opportunities that social relationships provide for development across domains (Bredekamp \& Copple, 1997). They underscore the necessity of classrooms where children learn how to develop and maintain friendships, resolve conflict, and participate in classroom governance. The popular guidelines encourage the establishment of a "caring community of learners" where teachers support the development of relationships between and among adults and children, thus providing both a context for learning and social and emotional development. Characteristics of this classroom community include class meetings where children consider social problems and agree on solutions (Lickona, 2001), teachers model and assist children in conflict resolution ( $\mathrm{Lo}-$ gan, 1998), and teachers involve children in rule-making and moral discussions (DeVries \& Zan, 1995; Rightmyer, 2003).

Researchers have noted that early classroom experiences are related to both positive and negative child outcomes. Hart, Yang, Charlesworth, and Burts (2003) explored the relationship between the developmental appropriateness of kindergarten teachers' classroom practices and child stress. They found that for children from kindergarten classrooms where teachers used developmentally inappropriate practices (DIP), child stress was related to growth of child aggression, hostility, and hyperactive/distractible behavior. In contrast, children developed behavior problems more slowly and gained in math abilities faster if they had been in kindergarten classrooms where teachers used developmentally appropriate practices (DAP). The authors suggest that growth trajectories beginning in kindergarten tend to persist into 3rd grade, even after taking into account pre-kindergarten readiness, child's gender, race, SES, and the type of 1st- and 2nd-grade classroom experiences (either DAP/DIP). Dunn and Kontos (1997) cite the effectiveness of DAP in benefiting children's motivation, attitudes about school, and level of stress. Research by DeVries, Reese-Learned, and Morgan 
(1991) indicates that early school experiences may have lasting effects on children's social interactive skills as well as their sociomoral development. Thus, an appropriate early childhood curriculum must consider not only cognitive development, but also must inculcate opportunities to develop positive peer relations, resolve conflict, and consider the perspectives of others in an atmosphere that supports emotional well-being.

While learning environments that support the development of pro-social skills appear to be critical to children's outcomes and a logical prerequisite to children's successful functioning in a democratic society, the power determining the classroom atmosphere clearly lies largely with the teacher. Teachers enter the classroom with a variety of influences upon how they will relate to children and the types of experiences that they will provide (Wein, 1995). How they choose to manage the behavior of their students is one decision teachers make that is freighted with implications for the teacher-child relationship and the child's future relationships with others. Interactions with early childhood teachers are directly related to the child's behavioral adjustment (Arnold, McWillliams, \& Harvey, 1998; Coplan \& Prakash, 2003; Howes \& James, 2002), and have been described as the "very heart of early childhood education" (Kontos \& Wilcox-Herzog, 1997). The importance of positive, nurturing relationships has been underscored by many early childhood professionals, who have even placed them above the academic dimensions of schooling (Brazelton \& Greenspan, 2001; DeVries, 2001).

Having noted the many problems facing some youth today, researchers have asserted that early positive relationships with adults exert a disproportionate influence upon the trajectories of children's later adjustment in school and the social processes that will guide them throughout life (Hamre \& $\mathrm{Pi}$ anta, 2001; Pianta, 1999; Pianta \& Walsh, 1996). Understanding this, it is noteworthy that some guidance or discipline strategies are more relationship-oriented than others, thus influencing the child's development in different ways. Positive discipline (Nelson, Lott, \& Glenn, 1993) is a management technique that encourages children to problemsolve and learn socialization rules without the negative associations that accompany other punitive methods. Because the word "discipline" itself often connotes the negative feelings associated with punishment, Gartrell (1997) promotes the use of "guidance," whereby teachers work with children, their parents, and other adults to teach children social skills, have developmentally appropriate expectations of children's behavior, and solve behavior problems through modeling and teaching. When teachers ask questions before they intervene, offer suggestions rather than commands, and listen instead of lecturing, they model an interactive style of relating to others and seeking solutions to problems that contributes to children's quality of social development (Katz \& McClellan, 1997).

This study was designed to determine if children from a kindergarten classroom in which the teacher used positive guidance strategies differed in their interpersonal relations and perspectives about school from children in a classroom in which the teacher exhibited negative guidance strategies.

\section{Methods}

Schools' reputations within the community have been used by previous researchers for sampling purposes (Hirsh-Pasek, Hyson, \& Rescorla, 1990; Hyson, Hirsh-Pasek, \& Rescorla, 1990; Rescorla, Hyson, HirshPasek, \& Cone, 1990). In the present study, two private schools known to endorse opposite guidance philosophies in their school programs were selected. Written school policies concerning guidance practices were used to verify the reputations of the schools. The schools had predominately white, middle- and upper-SES populations. From each of the schools, a teacher was selected whose guidance practices were reputed to be closely aligned with the school's philosophy. To verify the differences between the two teachers, a graduate student trained to use the observational instrument known as the Checklist for Rating Developmentally 
Appropriate Practice in Early Childhood Classrooms (Charlesworth et al., 1993) assessed the guidance strategies of the teachers by using the instrument's Guidance of Social-Emotional Development Subscale. The scores from the observation confirmed that the two teachers contrasted sharply in their use of guidance strategies. The teacher reputed to use negative guidance had a mean score of 2 , while the teacher reputed to use positive guidance had a mean score of 4.6 on a 5-point Likert scale on the Guidance of Social-Emotional Development Subscale (Charlesworth et al., 1993).

The teacher using positive guidance (PG) taught in a school with an enrollment of 397 students, grades pre-K through 12 . Her class, with an enrollment of 14 children, was one of three kindergartens at the school. The children had many opportunities to choose where they wanted to work and interact within the classroom. During whole-group activities, children sat in a semi-circle in small chairs facing the teacher. During center time, they moved freely around the room. They participated in such activities as building with big blocks; painting hand prints; playing dress-up in the housekeeping center; or sitting at a small round table or on the floor for private work, chatting, drawing, or resting. The teachers' interactions with the children included offering children choices of activities, coaching children through conflict situations, and friendly conversation. The teacher in this classroom often expressed affection for the children through hugs or pats on the back. Redirection was a frequent strategy for misbehavior.

The teacher using negative guidance (NG) taught in a school that had an enrollment of 338 students in grades pre-K through 12. Her kindergarten class was the only one in the school, and 23 children were enrolled in it. Most of the activities in this classroom were teacher-directed and the teacher determined the time frame in which "independent" activities occurred. During instruction, children were expected to sit straight with their feet on the floor and face the teacher. As a group, the children were asked "test" questions, were instructed in the formation of letters, and participated in a routine of daily recitation and songs. The teacher frequently criticized the children's behaviors in a tone of voice that conveyed authority. When children did not follow directions or disobeyed a rule, their names were written on the board after one warning. Other infractions resulted in the child being sent to the principal's office or losing recess privileges.

From each of these two kindergarten classrooms, three dyads of kindergartners were selected and paired boy-boy, girl-girl, boy-girl. To represent a spectrum of the city's residential areas, zip codes for the positive guidance classroom and the negative guidance classroom were matched within peer-pairs and with the corresponding peerpairs being observed in each school. For example, a boy-boy dyad from the positive guidance classroom would have the same zip code as the boy-boy dyad from the negative guidance classroom. Only children from two-parent homes were used for the study.

\section{Young Children's Enacted \\ Interpersonal Understanding}

Rather than coding the children's behavior from classroom observations, as done in previous research (DeVries, Reese-Learned et al., 1991), this study sought a more controlled setting and observed children interacting in a researcher-designed portable play-school center. Shelves provided the framework for the center, and plastic storage bins were used to hold materials. To simulate the various types of materials found in both classrooms, such items as housekeeping and dramatic play props, manipulatives, writing utensils, paper, books, and art supplies were included. On the side of the shelves, a basket was attached that held "teacher" props: a chalkboard; a ruler; an abacus; file folders; a clipboard; and a small plastic box that held chalk, pencils, clips, and stickers.

The subjects were videotaped a total of three times in the play-school center for 20 minutes each period during the months of September, October, and November. At both 
schools, the play-school center was set up in a separate classroom, and each of the three dyads from the positive guidance classroom and the negative guidance classroom were invited into the play center and given the opportunity to become familiar with the materials and the video camera. The children were told:

I'm trying to find out what it's like to be in kindergarten, and I need you to help me. I've brought this play-school center with toys for you to play school. One of you can be the teacher, and one of you can be the student. Then you can switch. You can play with anything on the shelves you want to play with.

Transcriptions of the videotaped interactions of the children playing in the playschool center were coded and analyzed independently by the first author and by two trained coders at monthly intervals and cumulatively, using the DeVries, Haney, and Zan (1991) coding manual. The two coders, graduate students in early childhood education, were blind to school and to teacher guidance strategies. Coder 1 had a 79 percent agreement with the first author on assignment of interactions to Negotiation Strategies or Shared Experiences and an 86 percent agreement on coding levels. Coder 2 had a 78 percent agreement on assignment of interactions to Negotiation Strategies or Shared Experiences and an 80 percent agreement on coding levels. Agreement was considered acceptable (DeVries, ReeseLearned, \& Morgan, 1991), and no attempt was made to resolve discrepancies in coding between the first author and the coders.

The coded behaviors were categorized into four levels of Shared Experiences, and three levels of Negotiation Strategies (DeVries, Haney et al., 1991; DeVries, Reese-Learned et al., 1991). Shared experiences are attempts at mutuality and occur when an interpersonal dynamic is in equilibrium. For example, children engaged in mimicking one another would be coded as a Shared Experience-Level 0 (SE-0), while dramatic play behavior with children engaged in complementary role-playing would be coded as a Shared Experience-Level 1 (SE-1).

Negotiation Strategies are attempts at autonomy and occur when an interpersonal dynamic is in disequilibrium (DeVries, Haney et al., 1991). Such behavior as withdrawing or hitting to solve a conflict would be categorized as a Negotiation StrategyLevel 0 (NS-0), while giving a reason for a choice would be categorized as a Negotiation Strategy-Level 2 (NS-2).

Levels 0 and 1 for both Shared Experiences and Negotiation Strategies include less mature interactions, while levels 2 and 3 indicate greater understanding and expression of interpersonal understanding. Expectations based on the DeVries, ReeseLearned et al. (1991) study were that because of the children's ages, the greater percentage of interactions would occur at Level 1, with the variations at the higher and lower levels reflecting differences based on classroom experience and the influence of teacher guidance strategies.

\section{The School Life Interview}

The School Life Interview, which was adapted from the DeVries, Reese-Learned et al. (1991) study, was administered individually to the child participants at the end of the third play-school session in November. The measure was used to ascertain children's personal perceptions of the schools' sociomoral atmosphere, adult authority figures, punishment, reasons for rules, respect for feelings of others, and personal responsibility for assisting and comforting others. A total of 19 open-ended questions were asked, including: "Who makes the rules in your class?"; "What do you think is the best thing to do when somebody hits you?"; "If somebody falls down and scrapes their knees so they bleed, what do children in your class do?"; and "Why do you come to school?"

$\quad$ Results
Shared Experiences and
Negotiation Strategies
Transcribed film coding, analyzed at
monthly intervals and cumulatively for the


three-month period, indicated differences in children's levels of Shared Experiences and Negotiation Strategies. Data are presented descriptively in Table 1. For the dyads in the PG classroom, the percentage of interactions for Shared Experiences was lower at Level 0 and higher at Level 2 when compared to the children in the NG classroom. This gap between the two groups widened over the three-month period (see Figure 1). Patterns in Negotiation Strategies fluctuated up and down for both groups during the three-month period (see Figure 2). However, results from the third play-school session show that at Level 0 , the percentage of interactions of the PG group is lower than the NG group, and higher at Level 2 than the percentage of those of the NG group (see Figure 2).

Interestingly, boys' interactions from the NG group started out in September with a higher percentage of Level 2 interactions for both Shared Experiences and Negotiation Strategies, but by the end of the three film sessions, their Level 2 interactions had dropped to below those of their PG counterparts (see Figures 3 and 4). Girls from the

Table 1

Composite of the Three Dyads' Scores in Each Kindergarten Classroom for the Three-Month Period

\begin{tabular}{|l|r|r|r|}
\hline Shared Experiences & Level 0 & \multicolumn{1}{c|}{ Level 1 } & \multicolumn{1}{c|}{ Level 2 } \\
\hline PG & $.46 \%$ & $68.5 \%$ & $30.9 \%$ \\
\hline$(\mathrm{N}=639)$ & $(3)$ & $(438)$ & $(198)$ \\
\hline $\mathrm{NG}$ & $17.9 \%$ & $71.7 \%$ & $10.3 \%$ \\
\hline$(\mathrm{N}=485)$ & $(87)$ & $(348)$ & $(50)$ \\
\hline & & & \\
\hline Negotiation Strategies & & & \\
\hline $\mathrm{PG}$ & $.65 \%$ & $68.4 \%$ & $30.9 \%$ \\
\hline$(\mathrm{N}=459)$ & $(3)$ & $(314)$ & $(142)$ \\
\hline $\mathrm{NG}$ & $22.2 \%$ & $61.3 \%$ & $16.3 \%$ \\
\hline$(\mathrm{N}=440)$ & $(98)$ & $(270)$ & $(72)$ \\
\hline
\end{tabular}

Note: PG-Positive Guidance Classroom, NG-Negative Guidance Classroom, N-Number of Interactions

Figure 1

Composite Shared Experiences at Levels 0 and 2 Over the Three-Month Period

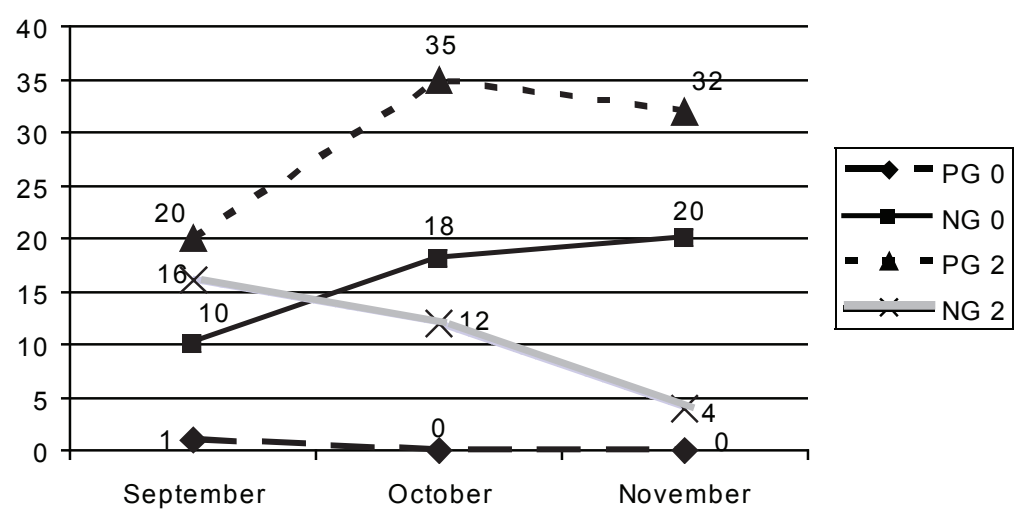


SCHMIDT, BURTS, DURHAM, CHARLESWORTH, AND HART

Figure 2

Composite Negotiation Strategies at Levels 0 and 2 Over the Three-Month Period



Figure 3

Boy Dyads Shared Experiences at Levels 0 and 2 Over the Three-Month Period

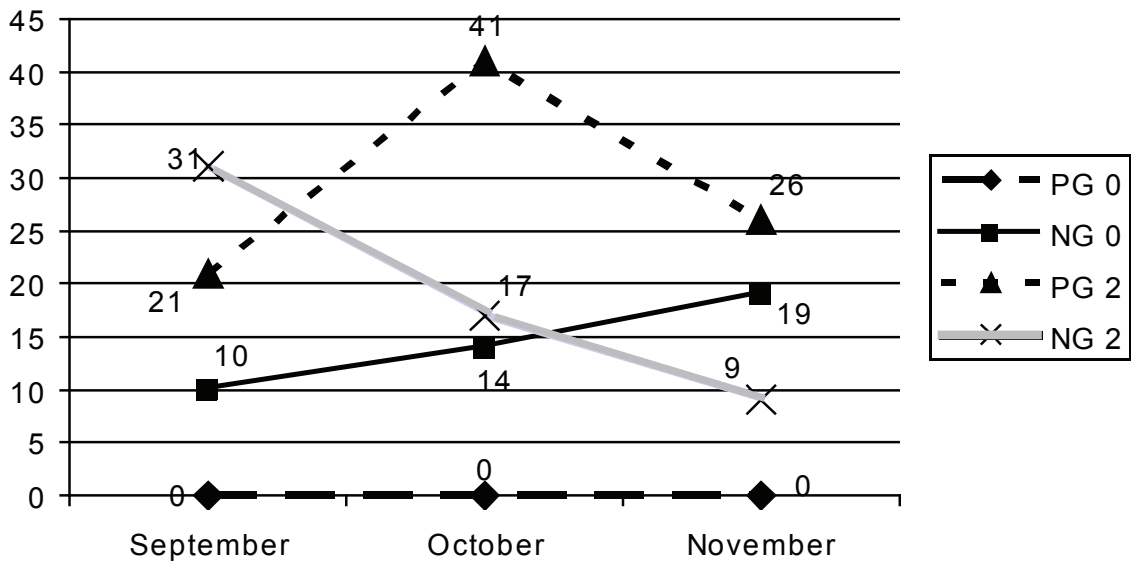

Figure 4

Boy Negotiation Strategies at Levels 0 and 2 Over the Three-Month Period

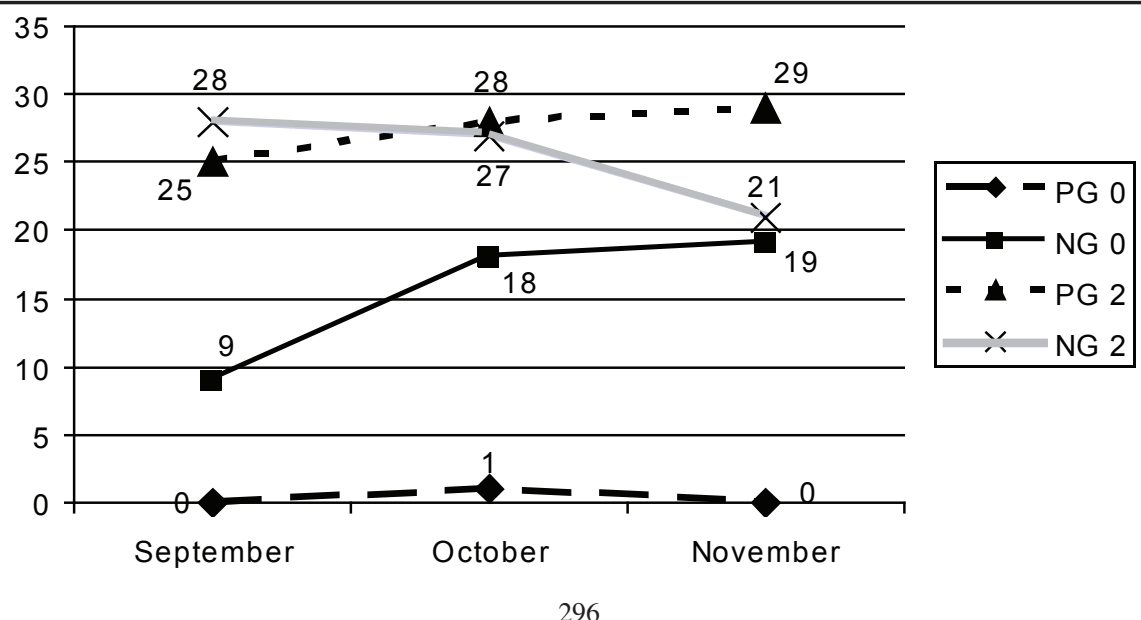


NG classroom seem to have fared worse than the other children. The NG girls had the highest percentage of Level 0 interactions for both Shared Experiences and Negotiation Strategies and the least Level 2 interactions for both Shared Experiences and Negotiation Strategies (see Figures 5 and 6).

\section{Responses to the School Life Interview}

In general, responses of the children on the School Life Interview seem to reveal differences in the ways that children perceived their roles within the classroom community. Children from the PG classroom seemed to exhibit a greater sense of autonomy and problem solving with peers when compared to the children from the NG classroom; children from the NG classroom seemed to depend on adults for problem solving and be less empathic of their peers. When asked, "What would you do if a friend got hurt on the playground?," the children from the PG classroom answered uniformly that they would try to help their friend by getting a Band-Aid, consoling her, or staying with her until she felt better. The children from the NG classroom uniformly responded, "I'd go get the teacher." When asked, "What would you do if someone hit you?," children from the PG classroom responded with such answers as, "I'd tell them not to do that," or "I'd tell them I didn't like that," and that "hitting back wouldn't help." Children from the NG classroom all responded that they would either tell the teacher or go to the office for help. When asked about their favorite activities, children from the PG classroom gave a variety of specific answers about the types

Figure 5

Girl Dyads Shared Experiences at Levels 0 and 2 Over the Three-Month Period

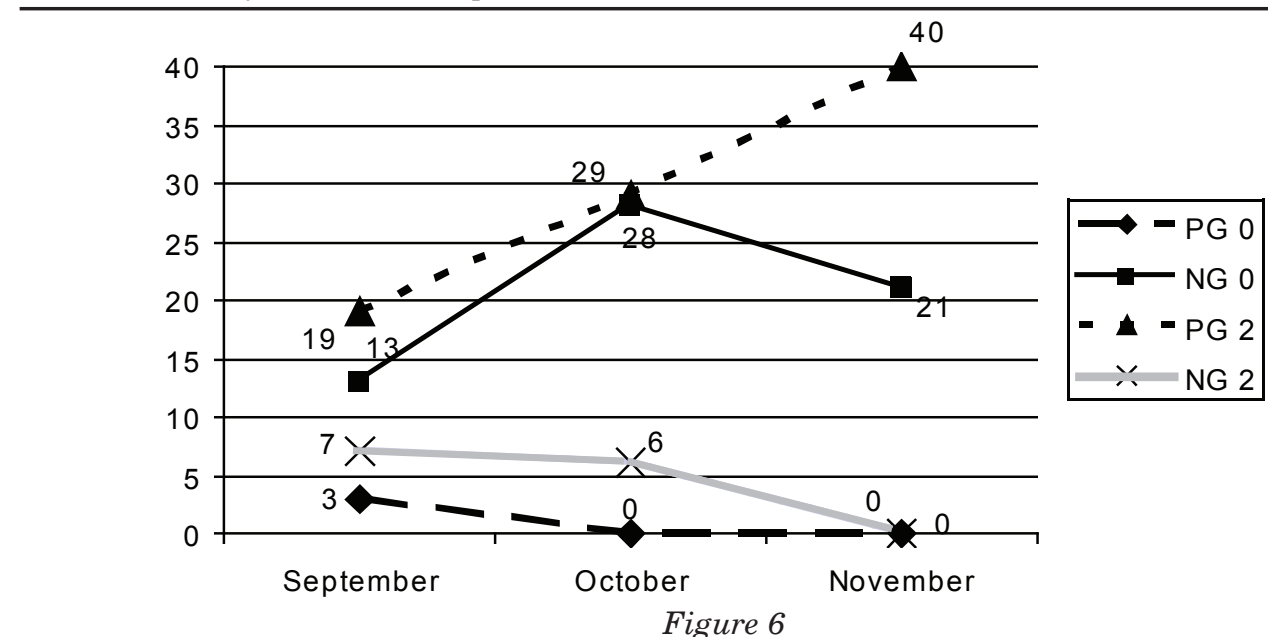

Girl Negotiation Strategies at Levels 0 and 2 Over the Three-Month Period




of activities that they preferred. Most of the children from the NG classroom said that "free time" was their favorite part of school. Another interesting result from the School Life Interview regards class decision-making. Children from the PG classroom spoke of making rules and even voting on some classroom activities. Conversely, children from the NG classroom uniformly stated that the teacher made all the rules, which, incidentally, the children defined as "things they couldn't do," and that did not know what it meant to vote.

\section{Discussion and Conclusion}

Although this study was limited by the sample size and duration, notable trends emerged between the children in the positive and negative guidance groups over the three-month period. The findings support the position of DeVries, Reese-Learned et al. (1991) that when children regularly experience an environment dominated by negative social modeling by the teacher, their development of higher level interpersonal understanding is limited. In addition, the evidence is in keeping with the study by Hart and colleagues (2003) that linked negative environmental factors (i.e., developmentally inappropriate practices) to negative outcomes for students through 3rd grade. Van Horn and colleagues (Van Horn, Karlin, Ramey, Aldridge, \& Snyder, 2005 ) noted that developmentally appropriate practice, which includes a teacher's use of positive guidance strategies, benefits children's psychosocial development.

In this study, both empirical evidence and the voices of children illustrate how quickly the teacher's choices of guidance strategies impact children's interpersonal relations and sociomoral development. One can infer from these findings that perhaps a teacher's guidance strategies contribute to an overall interpersonal "tone" within the classroom that influences the nature and quality of all the relationships therein. Not only does this influence seem to exist, unfortunately, it appears that negative classroom management techniques leave children void of the repertoire of skills needed to interact with peers successfully and to manage conflict.

Discussions of the differences between classroom environments and their corresponding effects upon children's sociomoral development often lead to the recurrent issue of curricular model. Curricular models seem to become embodied by teachers and the ways that they believe they must relate to children in order to achieve the objectives of the curriculum. Developmentally inappropriate practices are often accompanied by a sense that in order to transmit knowledge, teachers must confine children's behavior until knowledge can be successfully transmitted. Conversely, more developmentally appropriate practices are advanced by teachers who cooperatively guide children through experiences that scaffold new levels of learning. It is this idea of working "with" children, versus pushing children toward achievement, that has been shown to be associated with positive cognitive, social, and emotional outcomes (Dunn \& Kontos, 1997). Because DeVries, Reese-Learned et al. (1991) found that the academic advantages of developmentally inappropriate practices may fade by 3rd grade, and that positive teacherchild relationships regulate emotional and academic skill development throughout childhood (Pianta, 1999), it seems logical that the field of early childhood education should promote practices that are coupled with teacher attitudes and behaviors that do not threaten children's social and emotional development.

Many teachers do not deliberately choose negative guidance strategies, but rather operate from a variety of assumptions about their teaching role and effective strategies (Wein, 1995). Therefore, teachers may benefit from additional information about the importance of the sociomoral atmosphere that they maintain in their classrooms. It may be effective for teachers to view the creation of a positive sociomoral atmosphere as their first educational goal (DeVries, 2001). Beyond information, some teachers may benefit from instruction about effective 
strategies in managing classroom behavior without detriment to children's development. This need could be met through teacher education programs, thus equipping teachers with both the philosophical and methodological understanding of this domain before they begin their professional practice.

Currently, the practices of many schools and teachers overtly diminish children's opportunities for healthy development in the social realm. As well, adult models often inadvertently affect children's abilities to make friends, solve problems, and consider the perspectives of others. McCaslin and Good (1992) warn that "the best way to lose the next generation is to not teach them problem solving and coping skills in the social domain." It seems appropriate then for all agents responsible for the care and education of young children to come to a consensus on how best to provide a community environment that gives the child opportunities to interact in a positive and nurturing way with both adults and peers. As children experience the security and freedom that a caring classroom community can promote, one can expect that young citizens will continue to value and strive toward the good of the greater democracy.

While the results of this initial study support the established association between teachers' practices and children's developmental outcomes, replication on a larger scale would be advantageous. In addition, it seems that the broader attitudes and behaviors of the teacher shape the sociomoral atmosphere in the classroom that may be predictive of the results yielded in this study. To address the issues of securing accurate samples of different types of sociomoral atmospheres for further investigation, new measures are currently being developed (Durham \& Burts, 2006). In the present era of accountability and with a renewed call for investigation of the best practices for academic outcomes, we submit that further research should include the study of the sociomoral atmosphere in which they occur.

\section{References}

Arnold, D. H., McWilliams, L., \& Harvey, E. A. (1998). Teacher discipline and child misbehavior in preschool: Untangling causality with correlational data. Developmental Psychology, 74, 276-287.

Blaustein, M. (2005, July). See, hear, touch: The basics of learning readiness. Beyond the Journal, Young Children on the Web. Retrieved Oct. 2, 2005, from www.journal.naeyc. org/btj/200507/01Blaustein.pdf.

Brazelton, T. B., \& Greenspan, S. I. (2001). The irreducible needs of children. Young Children, 56(2), 6-14.

Bredekamp, S., \& Copple, C. (Eds.). (1997). Developmentally appropriate practice in early childhood programs (Rev. ed.). Washington, DC: National Association for the Education of Young Children.

Charlesworth, R., Hart, C. H., Burts, D. C., Thomasson, R. H., Mosley, J., \& Fleege, P. O. (1993). Measuring the developmental appropriateness of kindergarten teachers' beliefs and practices. Early Childhood Research Quarterly, 8, 255-276.

Coplan, R. J., \& Prakash, K. (2003). Spending time with teacher: Characteristics of preschoolers who frequently elicit versus initiate interactions with teachers. Early Childhood Research Quarterly, 18, 143-158.

DeVries, R. (2001). Constructivist education in preschool and elementary school: The sociomoral atmosphere as the first educational goal. In S. Golbeck (Ed.), Psychological perspectives on early childhood education: Reframing dilemmas in research and practice (pp. 153-180). Mahwah, NJ: Lawrence Erlbaum Associates.

DeVries, R., Haney, J., \& Zan, B. (1991). Socio-moral atmosphere in direct-instruction, eclectic, and constructivist kindergartens: A study of teachers' enacted interpersonal understanding. Early Childhood Research Quarterly, 6, 449-471.

DeVries, R., Reese-Learned, H., \& Morgan, P. (1991). Sociomoral development in direct-instruction, eclectic, and constructivist kindergartens: A study of children's enacted interpersonal understanding. Early Childhood Research Quarterly, 6, 473-517.

DeVries, R., \& Zan, B. (1994). Moral classrooms, moral children. New York: Teachers College Press.

DeVries, R., \& Zan, B. (1995). Creating a constructivist classroom atmosphere. Young 
Children, 51(1), 4-13.

Dunn, L., \& Kontos, S. (1997). What have we learned about developmentally appropriate practice? Young Children, 52(5), 4-13.

Durham, R. S., \& Burts, D. C. (2006, June). The sociomoral atmosphere in the early childhood classroom: Raising awareness in a standardsbased educational climate. Paper presented at the meeting of the National Association of Early Childhood Teacher Educators, San Antonio, TX.

Gartrell, D. (1997). Beyond discipline to guidance. Young Children, 52(6), 34-42.

Hamre, B. K., \& Pianta, R. C. (2001). Early teacher-child relationships and the trajectory of children's school outcomes through eighth grade. Child Development, 72, 625-638.

Hart, C. H., Newell, L. D., \& Olsen, S. F. (2003). Parenting skills and social/communicative competence in childhood. In J. O. Greene \& B. R. Burleson (Eds.), Handbook of communication and social interaction skills (pp. 753-797). Mahwah, NJ: Lawrence Erlbaum Associates.

Hart, C. H., Yang, C., Charlesworth, R., \& Burts, D. C. (2003, April). Kindergarten teaching practices: Associations with later child academic and social/emotional adjustment to school. Paper presented at the biennial meeting of the Society for Research in Child Development, Tampa, FL.

Hirsh-Pasek, K., Hyson, M. C., \& Rescorla, L. (1990). Academic environments in preschool: Do they pressure or challenge young children? Early Education and Development, 1, 401-423.

Howes, C., \& James, J. (2002). Children's social development within the socialization context of childcare and early childhood education. In P. K. Smith \& C. H. Hart (Eds.), Blackwell handbook of childhood social development (pp. 137-155). Oxford, UK: Blackwell Publishing.

Hyson, M. C., Hirsh-Pasek, K., \& Rescorla, L. (1990). The classroom practices inventory: An observation instrument based on NAEYC's guidelines for developmentally appropriate practices for 4- and 5-year-old children. Early Childhood Research Quarterly, 5, 475-494.

Katz, L. G., \& McClellan, D. E. (1997). Fostering children's social competence: The teacher's role. Washington, DC: National Association for the Education of Young Children.

Kontos, S., \& Wilcox-Herzog. (1997). Teachers' interactions with children: Why are they so important? Young Children, 52(2), 4-12.
Ladd, G. W., Buhs, E. S., \& Troop, W. (2002). Children's interpersonal skills and relationships in school settings: Adaptive significance and implications for school-based prevention and intervention programs. In P. K. Smith \& C. H. Hart (Eds.), Blackwell handbook of childhood social development (pp. 394-416). Oxford, UK: Blackwell Publishing.

Lickona, T. (2001). Creating the just community with children. Theory Into Practice, 16(2), 97-102.

Logan, T. (1998). Creating a kindergarten community. Young Children, 53(2), 22-26.

McCaslin, M., \& Good, T. (1992). Compliant cognition: The misalliance of management and instructional goals in current school reform. Educational Researcher, 21(3), 4-17.

McDaniel, G. L., Isaac, M. Y., Brooks, H. M., \& Hatch, A. (2005). Confronting K-3 teaching: Challenges in an era of accountability. Young Children, 60(2), 20-26.

National Association for the Education of Young Children. Critical facts. Retrieved October 31, 2005, from www.naeyc.org/ece/critical

Nelson, J., Lott, L., \& Glenn, H. S. (1993). Positive discipline in the classroom. Rocklin, CA: Prima.

No Child Left Behind Act of 2001. Pub. L. No. 107-110, §115 Stat, 1425 (2002).

Parke, R. D., Ornstein, P. A., Rieser, J. J., \& Zahn-Waxler, C. (1994). A century of developmental psychology. Washington, DC: American Psychological Association.

Piaget, J. (1965). The moral judgment of the child. London: Free Press. (Original work published 1932)

Pianta, R. C. (1999). Enhancing relationships between children and teachers. Washington, DC: American Psychological Association.

Pianta, R. C., \& Walsh, D. (1996). High-risk children in the schools: Creating sustaining relationships. New York: Routledge.

Rescorla, L., Hyson, M. C., Hirsh-Pasek, K., \& Cone, J. (1990). Academics expectations in mothers of preschool children: A psychometric study of the educational attitude scale. Early Education and Development, 1, 165-184.

Rightmyer, E. C. (2003). Democratic discipline: Children creating solutions. Young Children, 58(4), 38-45.

Teaching Tolerance. (1997). Starting small: Teaching tolerance in preschool and the early grades. Montgomery, AL: Southern Poverty Law Center.

Van Horn, M. L., Karlin, E. O., Ramey, S. L., Aldridge, J., \& Snyder, S. W. (2005). Effects 
of developmentally appropriate practices on children's development: A review of research and discussion of methodological and analytic issues. The Elementary School Journal, 105, 325-351.

Wein, C. A. (1995). Developmentally appropriate practice in real life. New York: Teachers College Press. 